\title{
ISOLASI NEMATODA PATOGEN SERANGGA STEINERNEMA DAN HETERORHABDITIS
}

\author{
Chaerani $^{1}$, Y. Suryadi ${ }^{1}$ T.P. Priyatno ${ }^{1}$, D. Koswanudin ${ }^{1}$, U. Rahmat ${ }^{1}$, \\ Sujatmo ${ }^{1}$, Yusuf ${ }^{1}$, dan C.T. Griffin ${ }^{2}$
}

\begin{abstract}
Isolation of Entomopathogenic Nematodes Steinernema and Heterorhabditis. Entomopathogenic nematodes from the genus Steinernema and Heterorhabditis (Rhabditida: Steinernematidae and Heterorhabditidae) are promising biological control agent of insect pests. Indigenous nematodes have been isolated and collected for the use in local biological control program of important insect pests. The nematodes were isolated using soil baiting method with insect larvae. Laboratory tests have shown that the mealworm larvae Tenebrio molitor (Coleoptera: Tenebrionidae) served as a good alternative to the standard insect bait, the greater wax moth larvae Galleria mellonella (Lepidoptera: Galleriidae) for isolation and maintenance of nematodes. Both nematodes were successfully isolated using T. molitor larvae from $13 \%$ soil samples (26 out of a total of 207) collected from 14 locations in West and Central Java and Lampung provinces in the period of 1993 until 2006. Heterorhabditis (9\%) was more prevalent than Steinernema (4\%). Both nematodes were successfully propagated on mealworm larvae.
\end{abstract}

Key words: biological control, entomopathogenic nematodes, soil baiting method

\section{PENDAHULUAN}

Nematoda dari genus Steinernema (Rhabditida: Steinernematidae) dan Heterorhabditis (Rhabditida: Heterorhabditidae) bersifat patogenik terhadap serangga sehingga menjadi jasad pengendali hayati yang prospektif (Kaya \& Gaugler, 1993). Stadia infektifnya adalah juvenil instar ketiga, atau biasa disebut sebagai juvenil infektif (JI) yang peralatan pencernaannya dorman dan hidup bebas di tanah di luar tubuh serangga. JI aktif mencari serangga, memasuki tubuh serangga melalui lubang-lubang alami dan membran antar skeleton. Setelah memasuki hemocoele serangga JI melepas bakteri simbion Enterobacteriaceae (Xenorhabdus spp. atau Photorhabdus luminescens) yang tersimpan di dalam saluran pencernaannya. Bakteri berbiak, membunuh serangga dengan menyebabkan keracunan darah (septicemia) sekaligus menyediakan kondisi yang sesuai untuk pertumbuhan dan reproduksi nematoda di dalam tubuh serangga.

JI mudah diisolasi dari tanah dengan cara mengumpankan larva serangga, biasanya larva greater wax moth (Galleria mellonella [Lepidoptera: Galleriidae]), pada tanah (Bedding \& Akhurst, 1975). Banyak peneliti yang telah berhasil mengisolasi nematoda patogen serangga (NPS) dari berbagai tempat di dunia dengan menggunakan larva ini, antara lain di Australia (Akhurst \& Bedding, 1986), Irlandia
(Blackshaw, 1988; Griffin et al., 1991), Inggris (Hominick \& Briscoe, 1990), Kanada (Mráček \& Webster, 1993), Amerika Serikat (Hara et al., 1991; Liu \& Berry, 1995), Sri Langka (Amarasinghe et al., 1994) dan Malaysia (Mason et al., 1996).

NPS introduksi telah diuji efektivitasnya untuk pertama kalinya di Indonesia terhadap hama rayap di perkebunan kelapa sawit dan dapat mengendalikan hingga 100\% (De Chenon et al., 1992). Penggunaan isolat endemik dianggap lebih baik daripada isolat introduksi karena isolat asli lebih mampu beradaptasi pada kondisi lokal (Liu \& Berry, 1995) dan kurang beresiko terhadap jasad hidup bukan sasaran (Blackshaw, 1988; Hara et al., 1991). Dalam rangka pengendalian hayati serangga hama penting di Indonesia Griffin et al. (2000) telah melakukan survei NPS di Bali, Ambon dan Seram dan berhasil mendapatkan spesies baru (Stock et al., 2004). Beberapa isolat telah diuji di rumah kaca dan dapat menyebabkan kematian hama lanas Cylas formicarius sebesar 43\% (Chaerani \& Waluyo, 1995) dan pengorok daun Liriomyza huidobrensis $70 \%$ (Yulensri et al., 2001), sedangkan di lapangan menyebabkan kematian kompleks penggerek batang padi (Scirpophaga spp., Chilo spp. dan Sesamia inferens) sebesar 67\% (Fallon, 1998).

Larva $G$. mellonella dianggap sebagai serangga yang paling rentan terhadap NPS dan telah menjadi umpan standar untuk memancing nematoda dari tanah

\footnotetext{
${ }^{1}$ Peneliti Balai Besar Penelitian dan Pengembangan Bioteknologi dan Sumber Daya Genetik Pertanian (BB-Biogen)

Jln. Tentara Pelajar 3A, Bogor 16111 Tel. 0251-337975, 339793, Fax. 0251-338820, e-mail : r.chaerani@ yahoo.com

${ }^{2}$ Dosen National University of Ireland Maynooth, Maynooth, Co. Kildare, Ireland
} 
(Bedding dan Akhurst, 1975). Serangga ini dalam keadaan normal tidak terpapar oleh nematoda sehingga diduga tidak mengembangkan mekanisme proteksi terhadap nematoda (Bedding \& Akhurst 1975). Walaupun mudah dibiakkan pada pakan buatan, larva ini sulit disediakan dalam jumlah besar dalam waktu singkat; sementara itu pada saat ini belum ada produsen yang menjualnya di Indonesia.

Tujuan penelitian ini ialah untuk mengisolasi NPS dari beberapa daerah di Indonesia yang belum dikunjungi pada survei sebelumnya oleh Griffin et al. (2000). Karena larva G. mellonella sulit diperoleh maka sebagai alternatifnya beberapa serangga diuji terlebih dahulu efektivitas dan efisiensinya untuk memancing dan memperbanyak NPS.

\section{METODE PENELITIAN}

Waktu dan tempat penelitian. Penelitian dilaksanakan di (dahulu) Laboratorium Nematologi BB-Biogen, terdiri dari (1) optimalisasi teknik isolasi NPS, dilakukan pada bulan Oktober 1992 dan JuliAgustus 1993, dan (2) isolasi NPS dari contoh tanah yang dikumpulkan dari sejumlah lokasi, dilakukan dari tahun 1993 sampai 2006 (Tabel 3).

Larva serangga. Ulat grayak (Spodoptera litura, Lepidoptera: Noctuidae) diperoleh dari tanaman sawi di Cipanas kemudian dipelihara pada daun talas. 'Ulat Hong Kong' (Tenebrio molitor, Coleoptera: Tenebrionidae) dan 'ulat cangkilung' (nama lokal Sunda; Lepidoptera, famili dan spesies tidak diketahui) berturut-turut diperoleh dari pedagang pakan burung dan pedagang peralatan pancing di Bogor. G. mellonella diperoleh dari sarang lebah di Bogor kemudian dipelihara pada pakan buatan (Poinar, 1975). Larva S. litura dan G. mellonella berada pada instar 5 atau 6 , sedangkan instar larva T. molitor dan 'ulat cangkilung' tidak diketahui namun mempunyai rata-rata berat tubuh per ekor berturut-turut 0,08 dan $0,43 \mathrm{~g}$.

NPS. H. indicus isolat INA H1 asal Anyer, Jawa Barat (Griffin et al., 2000) dan PLR2 (hasil isolasi dari salah satu survei yang kami laporkan dalam makalah ini) dan Steinernema isolat MACAU (diperoleh dari National University Maynooth, Ireland) diperbanyak pada larva G. mellonella menggunakan metode inokulasi kertas saring (Woodring \& Kaya, 1988).
Alas cawan Petri berdiameter $9 \mathrm{~cm}$ dilapisi dengan dua lembar kertas saring Whatman nomor 1 (diameter $9 \mathrm{~cm}$ ). Kepadatan nematoda ditentukan dari lima subcontoh (masing-masing $1 \mathrm{ml}$ ) yang diambil dari suspensi nematoda yang telah diencerkan. Nematoda $\left(0,1-0,2 \times 10^{3} \mathrm{JI} \mathrm{ml}^{-1}\right)$ dalam $0,7 \mathrm{ml}$ air keran diinfestasikan pada tiap kertas saring menggunakan pipet kaca. Dua puluh ekor larva diinfestasikan ke dalam cawan kemudian cawan ditutup dan diinkubasi selama 7 hari pada suhu kamar $\left(26 \pm 1,6^{\circ} \mathrm{C}\right)$ dalam keadaan gelap. Larva yang mati terinfeksi, yakni yang berubah warna menjadi coklat tua kemerahan jika terinfeksi oleh Heterorhabditis dan yang berubah warna menjadi coklat muda sedikit kehijauan jika terinfeksi oleh Steinernema, dipindahkan ke perangkap 'White' (Woodring dan Kaya, 1988 dengan sedikit modifikasi). Perangkap ini berupa cawan Petri berdiameter $15 \mathrm{~cm}$ berisi air keran setinggi $\pm 0,5 \mathrm{~cm}$ dan di tengahnya diletakkan alas atau tutup cawan Petri berdiameter $5 \mathrm{~cm}$. Larva yang terinfeksi Steinernema diletakkan berjajar di dalam alas cawan Petri $5 \mathrm{~cm}$ yang telah dialasi kertas tisu lembab. Larva yang terinfeksi oleh Heterorhabditis diletakkan dalam perangkap dengan model yang sedikit berbeda: tutup cawan Petri $5 \mathrm{~cm}$ ditelungkupkan ditengah cawan Petri $15 \mathrm{~cm}$ kemudian ditutup dengan kertas saring Whatman nomor 1 (diameter $9 \mathrm{~cm}$ ) yang tepiannya menyentuh permukaan air. Larva terinfeksi Heterorhabditis disusun berjajar di atas kertas saring. Setelah masa inkubasi selama 10 sampai 20 hari setelah inokulasi (HSI) pada suhu kamar dalam keadaan gelap air yang mengandung JI yang bermigrasi keluar dari tubuh serangga dipindahkan ke dalam gelas erlenmeyer. JI dicuci dengan air keran menggunakan metode sedimentasi-dekantasi sebanyak tiga sampai empat kali. Nematoda dengan konsentrasi $\pm 2,0 \times 10^{4} \mathrm{JI} \mathrm{ml}^{-1}$ air disimpan dalam $25-30 \mathrm{ml}$ air keran di dalam cawan-cawan Petri berdiameter $9 \mathrm{~cm}$ dan diletakkan dalam inkubator (Sanyo MIR-151) bersuhu $10 \pm 1,0^{\circ} \mathrm{C}$. Umur JI sebelum digunakan dalam penelitian tidak lebih dari dua minggu.

Pengujian spesies larva serangga sebagai umpan untuk mengisolasi NPS. Efisiensi $S$. litura, $T$. molitor, dan 'ulat cangkilung' untuk mengisolasi nematoda dari tanah dibandingkan dengan $G$. mellonella. Tanah dari kebun percobaan Cikeumeuh (Bogor, Jawa Barat) dan pasir dari pantai Pelabuhan Ratu (Sukabumi, Jawa Barat) dikeringanginkan 
kemudian disterilisasi dengan uap dalam autoklaf $\left(121^{\circ} \mathrm{C} ; 1,5 \mathrm{~atm}\right)$. Lima ekor larva dimasukkan ke dalam botol bekas selai (volume $250 \mathrm{ml}$ ) kemudian ditutupi dengan tanah atau pasir yang telah dilembabkan hingga memenuhi botol. Kadar air tanah dan pasir diatur berturut-turut sebesar 7 dan $15 \%$ (v/v). Dalam setiap botol terdapat satu spesies larva. Sebanyak 0,5 ml air keran mengandung $1,0 \times 10^{3} \mathrm{JI}$ diaplikasikan pada lubang sedalam $1 \mathrm{~cm}$ di atas permukaan tanah atau pasir yang kemudian ditutup kembali. Botol ditutup kemudian diinkubasi pada suhu kamar dalam keadaan gelap. Nematoda yang digunakan ialah Steinernema isolat MACAU dan $H$. indicus PLR2. Untuk setiap kombinasi perlakuan terdapat tiga ulangan. Percobaan menggunakan rancangan faktorial dengan rancangan dasar acak lengkap.

Persentase larva yang mati dengan gejala khas terinfeksi oleh nematoda mulai dicatat pada hari ketiga setelah inkubasi dari balik dasar botol tanpa membongkar tanah. Pada botol yang diinokulasi dengan Heterorhabditis pengamatan tambahan dilakukan di ruang gelap untuk melihat emisi cahaya (fluorescence) oleh larva yang terinfeksi. Pendaran cahaya ini dihasilkan oleh bakteri $P$. luminescens. Pada hari ke-7 semua larva dikeluarkan dari botol. Larva yang mati dengan gejala infeksi yang meragukan dibedah dan diamati dibawah mikroskop. Bila terdapat nematoda yang telah berpenetrasi dan berkembang maka larva dinyatakan terinfeksi oleh NPS.

\section{Pengujian spesies larva serangga untuk} mengetahui potensi reproduksi NPS. S. litura, 'ulat cangkilung' dan $T$. molitor dibandingkan efisiensinya untuk memperbanyak Steinernema MACAU dan $H$. indicus INAH1. Larva $(\mathrm{n}=10$, berat diketahui) diinokulasi dengan $1,0 \times 10^{3} \mathrm{JI} \mathrm{ml}^{-1}$ air menggunakan metode kertas saring seperti yang telah diterangkan sebelumnya. Untuk mengurangi tingkat kanibalisme antarlarva $S$. litura pakan berupa potongan daun talas yang telah dibilas dengan air juga diletakkan di dalam cawan Petri. Pada hari ke-7 masa inkubasi larva yang mati $(\mathrm{n}=5)$ dengan gejala khas terinfeksi NPS dipindahkan ke perangkap 'White'. Pemanenan JI dilakukan setiap hari hingga 20 HSI. Air dalam perangkap diperbaharui setiap kali panen. Total produksi JI ditentukan dari lima contoh hitung (masing-masing $1.0 \mathrm{ml}$ ) setelah dilakukan pengenceran suspensi JI. Percobaan menggunakan rancangan faktorial dengan rancangan dasar acak lengkap. Untuk setiap kombinasi perlakuan terdapat lima ulangan.

Isolasi NPS dari tanah. Survei terbatas dilakukan hampir setiap tahun mulai 1993 hingga 2006, kecuali pada tahun 1994, 1996, 1997, 2001 dan 2004. Lokasi yang dikunjungi kebanyakan adalah daerah berpasir. Tanah atau pasir diambil menggunakan soil corer atau sekop kecil pada kedalaman antara 10 sampai $15 \mathrm{~cm}$ kemudian dimasukkan ke dalam kantung plastik. Setiap kantung berisi 10 sampai 20 sub-contoh yang diambil dari hamparan seluas $\pm 0,1$ ha. Contoh tanah dan pasir dibawa ke laboratorium dan diletakkan dalam keadaan gelap pada ruang berpenyejuk udara $\left(\sim 22^{\circ} \mathrm{C}\right)$ sebelum digunakan. Bila agak kering tanah atau pasir dilembabkan terlebih dahulu dengan air keran. Tingkat kelembaban diukur dengan jari.

Setiap contoh dibolak-balik dalam kantung plastiknya agar tercampur rata kemudian dimasukkan ke dalam botol selai (kapasitas $300 \mathrm{ml}$ ) yang telah diisi dengan larva T. molitor atau G. mellonella (bila tersedia). Bila tersedia cukup banyak contoh tanah dibagi dua atau tiga dan masing-masing diumpan dengan serangga untuk memperbesar peluang mendapatkan NPS. Kondisi inkubasi dan metode pengamatan kematian serangga sama seperti yang telah diuraikan sebelumnya.

Larva yang terinfeksi nematoda dibilas di bawah air keran mengalir kemudian diinkubasi dalam perangkap 'White'. JI yang terkumpul diinokulasikan kembali pada larva G. mellonella atau T. molitor untuk menaikkan populasinya. Postulat Koch dan pemurnian NPS dari nematoda Rhabditida saprofitik dilakukan terhadap nematoda yang muncul dari serangga yang mati dengan gejala infeksi yang meragukan, misalnya warna khas infeksi tidak merata atau serangga berbau busuk.

Analisis statistik. Data persentase kematian serangga dan produksi JI dari hasil penelitian serangga alternatif dianalisis menggunakan prosedur ANOVA. Sebelum dianalisis kedua data ditransformasi terlebih dahulu ke dalam $\log$ (x) untuk menstabilkan keragaman. Pembedaan rata-rata perlakuan dilakukan menggunakan uji beda nyata terkecil (BNT) pada $P=$ 0,05 . 


\section{HASIL DAN PEMBAHASAN}

Larva alternatif untuk isolasi dan perbanyakan koleksi NPS. JI nematoda tertarik kepada dan aktif mencari serangga inang di dalam tanah untuk bereproduksi. Perilaku ini telah dimanfaatkan untuk mengisolasi nematoda secara mudah dari tanah dengan menaruh umpan berupa larva serangga seperti G. mellonella (Bedding \& Akhurst, 1975). Dalam penelitian kami tiga spesies serangga alternatif telah diuji untuk memancing JI yang diinokulasikan secara buatan pada media tanah atau pasir. T. molitor dan 'ulat cangkilung' dipilih karena banyak tersedia di pasar komersial sedangkan S. litura dipilih karena mudah dipelihara di laboratorium dan mempunyai potensi reproduksi tinggi.

Infektivitas Steinernema MACAU dan $H$. indicus PLR2 terhadap serangga ternyata tidak dipengaruhi oleh jenis media tanah (tanah atau pasir) maupun interaksi antara dua atau tiga faktor yang diteliti (larva $\times$ media tanah, larva $\times$ nematoda, media tanah $\times$ nematoda dan larva $x$ media tanah $\times$ nematoda), tetapi dipengaruhi oleh spesies larva atau nematoda $(P<0,001)$. Berdasarkan persentase kematian larva terlihat bahwa $T$. molitor dan 'ulat cangkilung' tidak berbeda nyata efektivitasnya dalam memancing nematoda dibandingkan dengan $G$. mellonella sehingga keduanya dapat digunakan sebagai larva umpan alternatif (Tabel 1).

Kemampuan reproduksi nematoda bergantung pada spesies serangga atau nematoda $(P<0,001)$ tetapi tidak dipengaruhi oleh interaksi antara spesies serangga $\times$ spesies nematoda. Walaupun $T$. molitor dan 'ulat cangkilung' keduanya dapat digunakan sebagai serangga umpan, jika ditinjau dari kemampuan memproduksi JI maka $T$. molitor merupakan alternatif terbaik setelah G. mellonella dibandingkan dengan 'ulat cangkilung' (Tabel 2). 'Ulat cangkilung' dan $S$. litura berpeluang menjadi perangkap mati bagi nematoda karena JI yang

Tabel 1. Persentase kematian tiga spesies larva umpan di dalam tanah atau pasir setelah diinokulasi dengan Steinernema MACAU dan Heterorhabditis indicus PLR2*

\begin{tabular}{lccc}
\hline Spesies larva umpan & Steinernema MACAU & H. indicus PLR2 & Rata-rata larva umpan** \\
\hline Galleria mellonella & 46,7 & 13,5 & $25,2 \mathrm{a}$ \\
Tenebrio molitor & 93,3 & 3,5 & $17,9 \mathrm{a}$ \\
'Ulat cangkilung' & 26,9 & 1,9 & $7,1 \mathrm{a}$ \\
Spodoptera litura & 1,9 & 1,7 & $1,8 \mathrm{~b}$ \\
\hline Rata-rata nematoda** & $21,6 \mathrm{x}$ & $3,5 \mathrm{y}$ & \\
\hline * Jenis media tanah, interaksi larva $\times$ media tanah, larva $\times$ nematoda, media tanah $\times$ nematoda dan larva $\times$ \\
media tanah $\times$ nematoda tidak berpengaruh nyata terhadap tingkat infeksi oleh nematoda pada $P=0,05$. \\
Angka-angka merupakan hasil transformasi balik dari log $(\mathrm{x})$ yang diperoleh dari tiga ulangan. \\
**Angka-angka dalam satu kolom atau satu baris yang diikuti oleh huruf yang sama tidak berbeda nyata \\
menurut uji BNT pada $P=0,05$.
\end{tabular}

Tabel 2. Potensi reproduksi Steinernema MACAU dan Heterorhabditis indicus INA H1 pada tiga spesies larva serangga*

\begin{tabular}{lccc}
\hline Spesies larva & $\begin{array}{c}\text { Steinernema MACAU } \\
\left(\times 10^{3} \mathrm{JI} \text { per larva }\right)\end{array}$ & $\begin{array}{c}\text { H. indicus INA H1 } \\
\left(\times 10^{3} \mathrm{JI} \text { per larva }\right)\end{array}$ & Rata-rata larva** \\
\hline Tenebrio molitor & 51,0 & 759,9 & $197,2 \mathrm{a}$ \\
'Ulat cangkilung' & 3,0 & 464,4 & $37,8 \mathrm{~b}$ \\
Spodoptera litura & 3,1 & 19,2 & $7,7 \mathrm{~b}$ \\
\hline Rata-rata nematoda** & $7,8 \mathrm{y}$ & $189,7 \mathrm{x}$ & \\
\hline
\end{tabular}

* Interaksi nematoda $\times$ larva tidak berpengaruh nyata terhadap potensi reproduksi nematoda pada $P=0,05$. Angka-angka hasil transformasi balik dari log (x) yang diperoleh dari lima ulangan.

**Angka-angka dalam satu kolom atau satu baris yang diikuti oleh huruf yang sama tidak berbeda nyata menurut uji BNT pada $P=0,05$. 
dihasilkan oleh kedua larva ini banyak yang mati. Hal ini diseababkan oleh tubuh kedua larva mudah terdisintegrasi dan debrisnya mencemari air; selanjutnya pencemaran ini dapat mengakibatkan berkurangnya kelarutan oksigen yang diperlukan oleh JI untuk bertahan hidup (Kung et al., 1990). Pada $S$. litura perkembangan stadia nematoda juga banyak terhenti pada fase reproduktif sebelum menghasilkan JI.

Jumlah JI yang dihasilkan oleh $H$. indicus INA H1 terlihat lebih tinggi daripada Steinernema MACAU. Generasi pertama Heterorhabditis yang bersifat hermafroditik menunjang kemampuan reproduksi yang lebih tinggi dibandingkan dengan Steinernema yang bersifat dimorfik pada setiap generasi (Kaya \& Gaugler, 1993).

Pengujian larva serangga untuk produksi NPS ini sayangnya tidak mengikutkan larva G. mellonella sebagai pembanding. Flanders et al. (1996) dapat memperoleh hingga 1,4 x $10^{6} \mathrm{JI}$ Heterorhabditis per gram larva G. mellonella, dua kali lipat dari yang kami peroleh pada larva T. molitor. De Chenon et al. (1992) melaporkan bahwa larva-larva dari ordo Lepidoptera seperti Tirathaba rufivena, Sethosea asigna, Corcyra cephalonica, Cadra cautella (syn. Ephestia cautella), Helicoverpa armigera, Pareuchaetes pseudoinsulata, dan Hidari irava yang dikumpulkan dari perkebunan kelapa sawit dan kelapa dapat digunakan untuk memperbanyak $S$. carpocapsae maupun Heterorhabditis namun mereka tidak mengungkapkan tingkat produksinya.

Peletakan serangga umpan di dalam botol dapat dilakukan dengan dua cara: (1) di dasar botol seperti yang digunakan dalam penelitian ini atau di atas permukaan tanah kemudian botol ditutup dan dibalik, dan (2) ditengah-tengah ketinggian botol diatas setengah bagian contoh tanah kemudian ditimbun dengan setengah bagian sisa tanah. Perbedaan tingkat infeksi serangga oleh nematoda antara kedua cara peletakan serangga diharapkan tidak terjadi. JI mampu bergerak secara vertikal ke atas dan bawah hingga jarak $15 \mathrm{~cm}$ maupun secara lateral dan daya jelajah ini semakin meningkat bila terdapat serangga (Schroeder \& Beavers, 1987; Nguyen \& Smart, 1990b). Botol yang digunakan untuk pengumpanan mempunyai ketinggian 10-11 cm, yang berada dalam jarak jelajah kebanyakan NPS.
Isolasi NPS. Sepanjang 13 tahun terakhir kedua genus nematoda telah diisolasi dari $13 \%$ contoh tanah atau 26 dari total 207 contoh tanah (Tabel 3). Tingkat perolehan ini sebanding dengan hasil survei di bagian timur Indonesia (12\%) oleh Griffin et al. (2000). Dari 14 lokasi yang dikunjungi, 9 diantaranya (64\%) mengandung nematoda. Steinernema berhasil didapatkan di P. Jawa sedangkan Griffin et al. (2000) yang hanya mensurvei satu lokasi di P. Jawa tidak berhasil mendapatkannya. Heterorhabditis lebih banyak terisolasi (18 dari 207 contoh tanah atau 9\%) daripada Steinernema (8 dari 207 contoh tanah atau $4 \%$ ). Jika isolat-isolat yang berasal dari satu lokasi pengambilan contoh dianggap sebagai satu isolat maka total ada 10 isolat nematoda yang diperoleh (tiga Steinernema dan tujuh Heterorhabditis). Frekuensi perolehan Heterorhabditis yang lebih tinggi daripada Steinernema juga dilaporkan oleh Akhurst \& Brooks (1984), Hara et al. (1991) dan Liu \& Berry (1995) di A.S. Sementara itu survei oleh Griffin et al. (2000) di Indonesia mendapatkan frekuensi deteksi yang sebanding antara Steinernema dan Heterorhabditis (6\%). Isolat Heterorhabditis dari Cisolok telah dideterminasi sebagai spesies indicus dan kemungkinan isolat lainnya juga berspesies sama karena hingga kini hanya indicus yang diketahui tersebar di daerah tropik (G. Poinar, komunikasi pribadi). Seluruh isolat Steinernema belum dideterminasi. Semua isolat berhasil diperbanyak pada larva T. molitor.

Kedua genus nematoda tidak pernah ditemukan secara bersamaan pada satu contoh tanah yang sama, namun dapat ditemukan pada lokasi yang sama dari titik pengambilan contoh tanah yang berbeda (Pangandaran) atau ditemukan pada lokasi yang berdampingan (misalnya Cisolok dan Karang Hau). NPS endemik di daerah Pacet, Cisolok, Karang Hau dan Cibangban karena selalu terdeteksi pada tahuntahun survei yang berbeda. Pada beberapa contoh tanah yang sama nematoda masih dapat terdeteksi pada pengumpanan kedua atau ketiga (data tidak diperlihatkan); berarti kepadatan nematoda cukup tinggi pada lokasi tersebut.

Survei yang dilakukan lebih bertujuan untuk mengumpulkan NPS dan tidak untuk mengetahui sebarannya sehingga pengambilan contoh tanah tidak dilakukan secara sistematis dengan memperhatikan tipe tanah atau vegetasi. Untuk meningkatkan peluang perolehan NPS upaya koleksi 
Tabel 3. Jumlah contoh tanah dan keberhasilan isolasi nematoda patogen serangga (NPS)

\begin{tabular}{|c|c|c|c|c|c|}
\hline Lokasi (dan kabupaten) & $\begin{array}{l}\text { Jumlah } \\
\text { contoh tanah }\end{array}$ & \multicolumn{3}{|c|}{$\begin{array}{l}\text { Jumlah contoh tanah yang positif mengandung } \\
\text { Steinernema Heterorhabditis Kedua NPS* }\end{array}$} & \multirow[t]{2}{*}{$\begin{array}{l}\text { Larva } \\
\text { umpan** }\end{array}$} \\
\hline \multicolumn{5}{|c|}{ Survei 1: Jawa Barat dan Jawa Tengah (Januari-Februari 1993) } & \\
\hline Kembaran (Banyumas) & 17 & 0 & 0 & $0(0,0)$ & $\mathrm{Tm}$ \\
\hline Muara (Bogor) & 5 & 0 & 0 & $0(0,0)$ & $\mathrm{Tm}$ \\
\hline Pacet (Cianjur) & 6 & 1 & 0 & $0(0,0)$ & $\mathrm{Tm}$ \\
\hline \multicolumn{6}{|c|}{ Survei 2: Jawa Barat dan D.I. Yogyakarta (Juli-Agustus 1993) } \\
\hline Parangtritis (Bantul) & 12 & 0 & 0 & $0(0,0)$ & $\mathrm{Tm}$ \\
\hline Cisolok (Sukabumi) & 2 & 0 & 1 & $1(50,0)$ & $\mathrm{Tm}$ \\
\hline Pelabuhan Ratu (Sukabumi) & 8 & 0 & 0 & $0(0,0)$ & $\mathrm{Tm}$ \\
\hline Ujung Genteng (Sukabumi) & 15 & 0 & 0 & $0(0,0)$ & $\mathrm{Tm}$ \\
\hline \multicolumn{6}{|c|}{ Survei 3: Jawa Barat (Agustus 1995) } \\
\hline Cisolok (Sukabumi) & 3 & 0 & 1 & $1(33,3)$ & $\mathrm{Tm}$ \\
\hline Karang Hau (Sukabumi) & 2 & 1 & 0 & $1(50,0)$ & $\mathrm{Tm}$ \\
\hline \multicolumn{6}{|l|}{ Survei 4: Jawa Barat (1998) } \\
\hline Cisolok (Sukabumi) & 9 & 0 & 1 & $1(11,1)$ & $\mathrm{Tm}$ \\
\hline Karang Hau (Sukabumi) & 2 & 0 & 0 & $0(0,0)$ & $\mathrm{Tm}$ \\
\hline \multicolumn{6}{|c|}{ Survei 5: Jawa Barat (Desember 1999) } \\
\hline Pacet (Cianjur) & 2 & 1 & 0 & $1(50,0)$ & $\mathrm{Gm}$ \\
\hline Pangandaran (Ciamis) & 13 & 4 & 2 & $6(46,2)$ & Gm, Tm \\
\hline Glempung Pasir (Cilacap) & 6 & 0 & 1 & $1(33,3)$ & $\mathrm{Gm}$ \\
\hline \multicolumn{6}{|l|}{ Survei 6: Jawa Barat (Juni 2000) } \\
\hline Pelabuhan Ratu (Sukabumi) & 10 & 0 & 0 & $0(0,0)$ & $\mathrm{Tm}$ \\
\hline Cisolok (Sukabumi) & 8 & 0 & 2 & $2(25,0)$ & $\mathrm{Tm}$ \\
\hline Karang Hau (Sukabumi) & 8 & 1 & 0 & $1(12,5)$ & $\mathrm{Tm}$ \\
\hline Cibangban (Sukabumi) & 8 & 0 & 1 & $1(12,5)$ & $\mathrm{Tm}$ \\
\hline \multicolumn{6}{|l|}{ Survei 7: Banten (Oktober 2002) } \\
\hline Merak (Serang) & 20 & 0 & 2 & $2(10,0)$ & $\mathrm{Tm}$ \\
\hline \multicolumn{6}{|c|}{ Survei 8: Lampung (September 2003) } \\
\hline Telukbetung (Lampung) & 25 & 0 & 3 & $3(12,0)$ & $\mathrm{Tm}$ \\
\hline \multicolumn{6}{|l|}{ Survei 9: Jawa Barat (Juli 2005) } \\
\hline Cibangban (Sukabumi) & 12 & 0 & 2 & $2(16,7)$ & $\mathrm{Tm}$ \\
\hline \multicolumn{6}{|c|}{ Survei 10: Jawa Tengah (Maret 2006) } \\
\hline Pantai Alam Indah (Tegal) & 14 & 0 & 2 & $2(14,3)$ & $\mathrm{Tm}$ \\
\hline Total & 207 & $8(3,9)$ & $18(8,7)$ & $26(12,6)$ & \\
\hline
\end{tabular}

*Angka-angka dalam kurung menyatakan persentase.

$* * \mathrm{Tm}=$ Tenebrio molitor, $\mathrm{Gm}=$ Galleria mellonella .

lebih banyak diarahkan ke daerah berpasir di tepi pantai. Frekuensi deteksi NPS yang lebih tinggi di daerah pantai telah dilaporkan oleh Hara et al. (1991) di Hawaii, Amarasinghe et al. (1994) di Sri Langka,
Liu \& Berry (1995) di Oregon, A.S. dan Mason et al. (1996) di Malaysia. Sementara itu Blackshaw (1988) dan Griffin et al. (1991) yang melakukan survei di daerah non-pantai Irlandia menemukan hubungan erat 
Tabel 4. Tekstur tanah dan vegetasi lokasi pengambilan contoh tanah

\begin{tabular}{|c|c|c|c|c|}
\hline Daerah & Habitat & Vegetasi & $\begin{array}{l}\text { Tekstur dan } \\
\text { kelembaban tanah }\end{array}$ & $\begin{array}{l}\text { Nematoda (dan } \\
\text { frekuensi deteksi) }\end{array}$ \\
\hline Telukbetung & Pantai & Ketapang dan waru & Pasir; lembab & Heterorhabditis (3) \\
\hline Merak & Pantai & Kelapa & Pasir; lembab & Heterorhabditis (2) \\
\hline Ujung & Pantai & Rumput, semak-semak, pandan, & Pasir bercampur & 0 \\
\hline $\begin{array}{l}\text { Genteng } \\
\text { Cibangban }\end{array}$ & Pantai & $\begin{array}{l}\text { kelapa dan pohon keras lainnya } \\
\text { Waru dan rumput }\end{array}$ & $\begin{array}{l}\text { kerikil; kering } \\
\text { Pasir; lembab }\end{array}$ & Heterorhabditis (3) \\
\hline Karanghau & Pantai & Rumput, Ipomoea sp., dan kelapa & Pasir; lembab & Steinernema $(2)$ \\
\hline Cisolok & Pantai & Rumput, Iротоеа sp., kelapa & Pasir; lembab & Heterorhabditis (5) \\
\hline $\begin{array}{l}\text { Pelabuhan } \\
\text { Ratu }\end{array}$ & Pantai & $\begin{array}{l}\text { Rumput, tanaman penutup tanah, } \\
\text { kelapa dan pohon keras lainnya }\end{array}$ & Pasir; lembab & 0 \\
\hline Muara & Pertanian & Kedelai dan ubi jalar & Lempung; basah & 0 \\
\hline Pacet & Pertanian & Kedelai dan ubi jalar & $\begin{array}{l}\text { Lempung berpasir; } \\
\text { lembab }\end{array}$ & Steinernema (2) \\
\hline Pangandaran & Pantai & Kelapa dan rumput & Pasir; lembab & $\begin{array}{l}\text { Steinernema }(4) \\
\text { Heterorhabditis }(2)\end{array}$ \\
\hline $\begin{array}{l}\text { Glempung } \\
\text { Pasir }\end{array}$ & Perkebunan & Kelapa, pisang, nanas, jeunjing & Pasir; lembab & Heterorhabditis (1) \\
\hline Kembaran & Perkebunan & Kelapa, rumput & Lempung; lembab & 0 \\
\hline Parangtritis & Pantai & $\begin{array}{l}\text { Rumput, kedelai, pandan, semak } \\
\text { belukar, kelapa }\end{array}$ & Pasir; agak kering & 0 \\
\hline $\begin{array}{l}\text { Pantai Alam } \\
\text { Indah }\end{array}$ & Pantai & Ketapang, waru, akasia, kelapa & Pasir; lembab & Heterorhabditis (2) \\
\hline
\end{tabular}

antara NPS dan tanah bertekstur pasir dan mengandung humus. Pada survei kami NPS banyak diperoleh dari daerah pantai yang pasirnya lembab (Tabel 4). NPS tidak terdeteksi di pantai-pantai Ujung Genteng dan Parangtritis; kedua daerah ini kondisi pasirnya kering. Di daerah pedalaman yang dibudidayakan secara intensif NPS juga terdeteksi, yakni di Glempung Pasir yang tanahnya berpasir dan di Pacet yang tanahnya bertekstur ringan. Adanya variasi dalam metode dan jumlah pengambilan contoh antar survei tidak memungkinkan untuk diadakannya analisis korelasi antara perolehan nematoda dengan jenis tanah. Percobaan laboratorium oleh Georgis \& Poinar (1983a, b) dan oleh Molyneux \& Bedding (1984) dapat membantu menjelaskan hubungan antara tingkat parasitisasi serangga oleh NPS dengan kandungan fraksi pasir dan kadar air secara umum. Peningkatan kandungan pasir berpengaruh positif terhadap mobilitas nematoda (Georgis \& Poinar, 1983a, b; Molyneux \& Bedding, 1984) maupun serangga (Griffin et al., 1991) dan meningkatkan parasitisasi serangga oleh nematoda. Sementara itu kandungan air pada pasir berkorelasi positif dengan tingkat parasitisasi NPS sedangkan pada tanah berlempung korelasinya negatif (Molyneux \& Bedding, 1984).

Contoh tanah diambil pada tempat-tempat yang bervegetasi karena keberadaan tanaman erat hubungannya dengan keberadaan serangga pengganggunya. NPS dapat ditemukan pada hampir semua jenis tanaman baik yang dibudidayakan maupun tidak (Tabel 4). Karena lokasi dan jumlah contoh yang kami ambil bervariasi, maka pengaruh tipe habitat tanaman terhadap perolehan NPS juga tidak dapat ditentukan. Laporan dari beberapa peneliti mengenai hubungan antara perolehan NPS dengan jenis habitat bertentangan. Misalnya, Akhurst \& Brooks (1984) dan Liu \& Berry (1995) mendeteksi lebih banyak NPS di daerah yang belum mendapat campur tangan manusia seperti di hutan atau pantai daripada daerah pertanian intensif termasuk perkebunan sedangkan Mráček \& Webster (1993) mendeteksi lebih banyak NPS di daerah yang dibudidayakan secara intensif. Aplikasi pestisida dan pupuk pada daerah pertanian monokultur yang intensif bisa berdampak negatif pada daya bertahan nematoda 
(Liu \& Berry, 1995) namun sebaliknya juga dapat menimbulkan ledakan serangga hama yang berpotensi menjadi serangga inang NPS (Mráček \& Webster, 1993). Jadi perbedaan sebaran nematoda lebih ditentukan oleh perbedaan sebaran serangga inang dan juga oleh spesies nematoda ketimbang oleh jenis habitat. Selama survei tidak pernah ditemukan serangga yang terinfeksi nematoda sehingga inang alami NPS tidak diketahui. Beberapa spesies diketahui mempunyai preferensi inang, contohnya $S$. scapterisci yang hanya dapat bereproduksi pada Scapteriscus (Nguyen \& Smart, 1990a). Spesifitas inang yang tinggi ini dapat menjadi penyebab kegagalan serangga non-inang, yang sekalipun rentan secara universal, untuk mendeteksi semua isolat NPS yang ada di tanah.

\section{SIMPULAN}

Larva T. molitor dapat digunakan untuk mengisolasi NPS dari tanah dan memperbanyaknya. Hasil survei kami dan Griffin et al. (2000) menunjukkan bahwa NPS lokal mudah ditemukan di Indonesia. Jumlah yang diperoleh masih dianggap sebagai batas minimum kelimpahan di Indonesia karena belum semua daerah terwakili. Perluasan wilayah survei dan pengambilan contoh tanah lebih banyak secara sistematik dapat menghasilkan strain ataupun spesies baru, terutama untuk Steinernema.

\section{SANWACANA}

Kami berterima kasih kepada Suhendra, Rahmat dan Suci Widiati atas bantuan di laboratorium dan Dr George Poinar (Oregon State University) atas budi baik mengidentifikasi isolat Heterorhabditis. Penelitian didanai oleh EU proyek nomor TS3*CT920018 dan APBN. Makalah ini bernomor registrasi 3-06-018 di BB-Biogen.

\section{DAFTAR PUSTAKA}

Akhurst, R.J. \& R.A. Bedding. 1986. Natural occurrence of insect pathogenic nematodes (Steinernematidae and Heterorhabditidae) in soil in Australia. J. Aust. ent. Soc. 25: 241244.

Akhurst, R.J. \& W.M. Brooks. 1984. The distribution of entomophilic nematodes
(Heterorhabditidae and Steinernematidae) in North Carolina. J. Invertebr. Pathol. 44: 140145.

Amarasinghe, L.D., Hominick, W.M., Briscoe, B.R., \& Reid, A.P. 1994. Occurrence and distribution of entomopathogenic nematodes in Sri Lanka. J. Helminthol. 68: 277-286.

Bedding, R.A. \& R.J. Akhurst. 1975. A simple technique for the detection of insect parasitic rhabditid nematodes in soil. Nematologica 21(1): 109-110.

Blackshaw, R.P. 1988. A survey of insect parasitic nematodes in Northern Ireland. Ann. appl. Biol. 113: 561-565.

Chaerani \& Waluyo. 1996. Potensi nematoda patogen serangga Steinernema dan Heterorhabditis (Rhabditida: Steinernematidae, Heterorhabditidae) sebagai pengendali hayati hama lanas Cylas formicarius F. (Coleoptera: Apionidae). Makalah disajikan dalam Seminar Nasional Pegnendalian Hayati, Yogyakarta 5-7 Agustus 1996.

De Chenon, R.D., A. Sipayung, \& Soedharto Ps. 1992. Use of entomogenous nematodes against Coptotermes curvignathus Holmgren, Rhinotermitidae. Buletin Pusat Penelitian Perkebunan Marihat 12(2): 9-17.

Fallon, D.J. 1998. The use of indigenous entomopathogenic nematodes (Heterorhabditis indica and Steinernema spp.) to control rice stem borer in West Java, Indonesia. PhD thesis, National University of Ireland, Maynooth.

Flanders, K.L., J.M. Miller, \& E.J. Shields. 1996. In vivo production of Heterorhabditis bacteriophora 'Oswego' (Rhabditida: Heterorhabditidae), a potential biological control agent for soil-inhabiting insects in temperate regions. J. Econ. Entomol. 89(2) : 373-380.

Georgis, R. \& G.O. Poinar Jr. 1983a. Effect of soil texture on the distribution and infectivity of Neoaplectana carpocapsae (Nematoda: 
Steinernematidae). J. Nematol. 15(3): 308311.

Georgis, R. \& G.O. Poinar Jr. 1983b. Effect of soil texture on the distribution and infectivity of Neoaplectana glaseri (Nematoda: Steinernematidae). J. Nematol. 15(3): 329332.

Griffin, C.T., J.F. Moore, \& M.J. Downes. 1991. Occurrence of insect-parasitic nematodes (Steinernematida, Heterorhabditidae) in the Republic of Ireland. Nematologica 37: 92100.

Griffin, C.T., R. Chaerani, D. Fallon, A.P. Reid, \& M.J. Downes. 2000. Occurrence and distribution of the entomopathogenic nematodes Steinernema spp. and Heterorhabditis indica in Indonesia. J. Helminthol. 74: 143-150.

Hara, A.H., R.Gaugler, H.K. Kaya, \& L.M. Lebeck. 1991. Natural populations of entomopathogenic nematodes (Rhabditida: Heterorhabditidae, Steinernematidae) from the Hawaiian Islands. Environ. Entomol. 20: 211-216.

Hominick, W.M. \& B.R. Briscoe. 1990. Occurrence of entomopathogenic nematodes (Rhabditida: Steinernematidae and Heterorhabditidae) in British soils. Parasitol. 100, 295-302

Kaya, H.K. \& R. Gaugler. 1993. Entomopathogenic nematodes. Annu. Rev. Entomol. 38: 181-206.

Kung, S., R. Gaugler, \& H.K. Kaya. 1990. Influence of soil $\mathrm{pH}$ and oxygen on persistence of Steinernema spp. J. Nematol. 22(4): 440-445.

Liu, J. \& R.E. Berry. 1995. Natural distribution of entomopathogenic nematodes (Rhabditida: Heterorhabditidae and Steinernematidae) in Oregon soils. Environ. Entomol. 24(1): 159163.

Mason, J.M., A.R. Razak, \& D.J. Wright. 1996. The recovery of entomopathogenic nematodes from selected areas within Peninsular Malaysia. J. Helminthol. 70: 303-307

Molyneux, A.S. \& R.A. Bedding. 1984. Influence of soil texture and moisture on the infectivity of
Heterorhabditis sp. D1 and Steinernema glaseri for larvae of the sheep blowfly, Lucilia cuprina. Nematologica 30: 358-365.

Mráček, Z. \& J.M. Webster. 1993. Survey of Heterorhabditidae and Steinernematidae (Rhabditida, Nematoda) in Western Canada. Nematologica 25(6): 710-717.

Nguyen, K.B. \& G.C. Smart. 1990a. Steinernema scapterisci n. $\quad$ sp. (Rhabditida: Steinernematidae). J. Nematol. 22(2): 187199.

Nguyen, K.B. \& G.C. Smart. 1990b. Vertical dispersal of Steinernema scapterisci. J. Nematol. 22(4): 574-578.

Poinar, G.O. Jr. 1975. Entomogenous nematodes. E.J. Brill. Leiden, Netherlands.

Schroeder, W.J. \& J.B. Beavers. 1987. Movement of the entomogenous nematodes nematodes of the families Heterorhabditidae and Steinernematidae in soil. J. Nematol. 19(2): 257-259.

Stock, S.P., C.T. Griffin, \& R. Chaerani. 2004. Morphological and molecular characterisation of Steinernema hermaphroditum n. sp. (Nematoda: Steinernematidae), an entomopathogenic nematodes from Indonesia, and its phylogenetic relationships with other member of the genus. Nematology 6 (3): 401 412.

Woodring, J.L. \& H.K. Kaya. 1988. Steinernematid and Heterorhabditid nematodes: a handbook of biology and techniques. Southern Cooperative Series Bulletin 331. Arkansas Agricultural Experiment Station, Fayetville, Arkansas.

Yulensri, T. Santoso, A. Rauf, \& Chaerani. 2001. Uji keefektifan nematoda entomopatogen Heterorhabditis indicus dan Steinernema riobravis terhadap hama pengorok daun Liriomyza huidobrensis (Blanchard) (Diptera: Agromyzidae). Simposium Pengendalian Hayati Serangga, Sukamandi, 14-15 Maret 2001. 